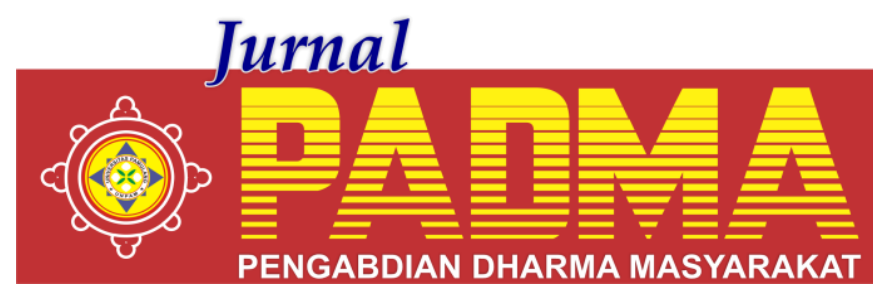

VOLUME 1, NOMOR 4, OKTOBER 2021

\title{
PELATIHAN AKUNTANSI KEUANGAN BAGI SISWA SMK KARTINI SURABAYA
}

\author{
${ }^{1 *}$ Soemaryono, ${ }^{2}$ Rudi Pratono, ${ }^{3}$ Ismangil \\ Universitas Wijaya Kusuma, Surabaya, Indonesia \\ *maryonofeuwks@gmail.com
}

\begin{abstract}
Abstrak
Tujuan dari kegiatan pengabdian masyarakat ini adalah untuk meningkatkan keterampilan sumber daya manusia, dengan memberikan pembinaan pengetahuan dan keterampilan dalam laporan keuangan dengan standar akuntansi. Sasaran pengabdian masyarakat adalah siswa SMK Kartini Surabaya yang berdomisili di wilayah Surabaya. Diharapkan mahasiswa setelah mengikuti kegiatan pengabdian masyarakat dapat memahami konsep dasar akuntansi, prinsip akuntansi, persamaan akuntansi dan mampu Menyusun laporan keuangan dengan pernyataan standar akuntansi keuangan (PSAK). Metode pengabdian masyarakat dengan memberikan materi pengetahuan teoritis dan praktik. Hasil kegiatan pengabdian masyarakat adalah siswa dapat memahami konsep dasar akuntansi, prinsip akuntansi, persamaan akuntansi dan mampu Menyusun laporan keuangan dengan pernyataan standar akuntansi keuangan. Laporan keuangan perusahaan jasa, perusahaan dagang, dan perusahaan manufaktur.
\end{abstract}

Kata Kunci: Konsep, Laporan Keuangan Persamaan Akuntansi, Prinsip Akuntansi

\section{Abstract}

The purpose of this community service is to improve human resource skills, by providing knowledge and skills development in financial reporting with accounting standards. The target are students of SMK Kartini Surabaya who are domiciled in Surabaya area. It's expected the students after participating in this community service activity can be understand the basic concept of accounting, accounting principles, accounting equations and able to prepare financial statements with the statement of financial accounting standards (PSAK). The methods of community service by providing knowledge material theoretical and practical. The results by students service activities are they can understand the basic concept of accounting, accounting principles, accounting equations and able to prepare financial statements with the statement of financial accounting standards. The Financial statements of service companies, trading companies, and manufacture companies.

Keywords: Accounting Equations, Accounting Principle, Concept, Financial Statements

\section{PENDAHULUAN}

Akuntansi merupakan kegiatan jasa yang memberikan informasi bagi pihakpihak yang berkepentingan. Salah satu yang diperlukan untuk memperoleh informasi akuntansi ini adalah digunakan sebagai bahan pengambilan keputusan ekonomi bagi pihak yang memerlukan. Akuntansi tidak hanya diperlukan oleh perusahaan yang bersifat bisnis, tetapi diperlukan juga oleh pihak yang secara individual, pemerintahan, organisasi social, organisasi kemasyarakatan maupun organisasi politik. Karena jasa informasi akuntansi diperlukan berbagai pihak maka diperlukan proses penyusunan akuntansi yang yang sesuai dengan standar akuntansi yang berterima umum dalam hal ini pernyataan standar akuntansi keuangan yang berlaku di negara Indonsia. Sehingga proses akuntansi akan menghasilkan laporan keuangan yang secara wajar dalam arti sesuai dengan standar akuntansi keuangan yang berterima umum.

Pemahaman konsep akuntansi keuangan yang berterima umum ini dilakukan dengan cara sosialisasi oleh para akuntan baik akuntan yang bekerja di sektor dunia usaha, sector Pendidikan, maupun sector lainnya. Untuk mengenalkan standar akuntansi keuangan yang berlaku umum dalam prnyusunan laporan keuangan yang wajar bisa dilakukan lewat jalur Pendidikan formal maupun lewat jalur Pendidikan non formal. Salah satunya jalur Pendidikan formal melalui pendidikan khusus bidang akuntansi yakni sekolah menengah kejuruan. Sekolah menengah kejuruan dengan program studi atau jurusan akuntansi 
merupakan Lembaga atau sekolah yang mencetak siswa memeliki ketrampilan atau keahlian bidang akuntansi sehingga lulusannya disiapkan untuk langsung siap bekerja. Sekolah menengah kejuruan jurusan akuntansi ini sebuah Langkah yang tepat untuk mengembangkan dan mengenalkan konsep-konsep akuntansi, karena sekolah kejujuran diharapkan menghasilkan sumber daya yang siap untuk bekerja sesuai bidangnya. Dalam hal pengembangan akuntansi terhadap anak didik sejak dini maka diperlukan sekolah menengah kejuruan jurusan atau program studi akuntansi. Dengan adanya jurusan atau program studi akuntansi maka materi yang diberikan kepada anak didik atau siswa bisa menghasilkan lulusan akuntansi yang kompeten maupun kredibel.

\section{METODE}

Bentuk atau metode kegiatan kepada masyarakat ini dikemas dalam bentuk workshop dalam arti kegiatan pelatihan yang mefokuskan pada kegiatan praktek. Sehingga secara langsung bisa memberikan pengertian dan pemahaman sekaligus mengerti yang sesuai terhadap permasalahan yang dihadapi peserta yaitu dalam menusun laporan keuangan yang sesuai dengan standar akuntansi keuangan (SAK) yang brlaku umum. Untuk mengatasi permasalahan yang dihadapi peserta maka dilakukan bebrapa tindakan pelaksanaan kegiatan ini yang meliputi tahapan-tahapan sebagai berikut :

a. Ceramah materi pelatihan yang meliputi filosofi teori akuntansi, konsep dasar akuntansi dan prinsip akuntansi.

b. Ceramah materi pelatihan yang meliputi pemhaman konsep proses atau siklus akuntansi, persamaan akuntansi, konsep penjurnalan, metode atau perlakuan akuntansi akuntansi, pemahaman pengertian standar akuntansi keuangan (SAK) dan pemahaman teori dasar penyusunan laporan keuangan yang sesuai dengan standar akuntansi keuangan yang berlaku di Indonesia.

c. Pelatihan dalam bentuk mengerjakan modul atau studi kasus dalam bentuk praktek yang diawali dengan membuat jurnal transaksi baik jurnal umum maupun jurnal khusus. d. Praktek Mengerjakan buku besar, buku pembantu , membuat jurnal penyesuaian dan menyususun neraca lajur

e. Praktek Menyusun laporan keuangan perusahaan yang meliputi laporan posisi keuangan, atau neraca, Menyusun laporan laba rugi, laporan perubahan ekuitas dan laporan arus kas perusahaan

f. Praktek Menyusun catatan atas laporan keuangan

\section{HASIL DAN PEMBAHASAN}

Dalam pelaksanaan kegiatan pengabdian kepada masyarakat yang dilaksanakan pada siswa atau anak didik Sekolah Menengah Kejuruan (SMK) Kartini Surabaya dapat diperoleh hasil kegiatan sebagai berikut

a. Faktor pendukung terlaksananya kegiatan pengabdian masyarakat antara lain

1. Antusias kepala sekolah, guru maupun siswa peserta kegiatan yang cukup tinggi sehingga Kegiatan bisa lancar dan bisa sesuai harapan

2. Para siswa peserta kegiatan merupakan siswa jurusan akuntansi, sehingga bisa menunjang percepatan materi yang disampaikan para team pengabdian masyarakat

3. Fasilitas kegiatan yang cukup memadai sebagai tempat kegiatan karena dalam ruang tempat kegiatan ada sarana $\mathrm{AC}$, LCD, Kipas Angin, Sound System dengan system Wireless dan sarana alat tulis lainnya

4. Lokasi ruangan yang jauh dari jalan sehingga dalam proses kegiatan tidak terganggu oleh suara bising lalu Lalang kendaraan maupun suara lainnya.

b. Faktor Penghambat

Faktor penghambat yang dirasakan dalam pelaksanaan kegiatan pengabdian masyarakat Kondisi pandemi covid-19 membuat para sisa atau para peserta merasa ada keterbatasan dalam berinteraksi baik dengan sesama peserta maupun dengan para team pengabdian masyarakat. Hal Ini bisa dilihat atau dirasakan pada saat mengerjakan tugas kelompok yang diberikan oleh Team. Yang mana dalam mengerjakan tugas maupun diskusi kelompok seperti terjadi Adanya saling berusaha menjaga jarak antara yang satu dengan yang lainnya. 
Hasil Kegiatan

Dari evaluasi pada saat akan berakhirnya kegiatan maupun pada saat sudah selesainya pelaksanaan kegiatan pengabdian kepada masyarakat, maka dapat diperoleh hasil yang dicapai kegiatan ini sebagai berikut

1. Peserta mampu memahami secara konsep , bukan secara hafalan tentang konsep dasar akuntansi dan prinsip akuntansi secara umum

2. Peserta mampu memahami secara konseptual tentang persamaan akuntansi, metode perlakuan akuntansi serta jurnal transaksi dalam laporan keuangan

3. Peserta mampu memahami secara konseptual proses atau siklus akuntansi dalam penyusunan laporan keuangan

4. Peserta mampu memahami konseptual laporan posisi keuangan dan

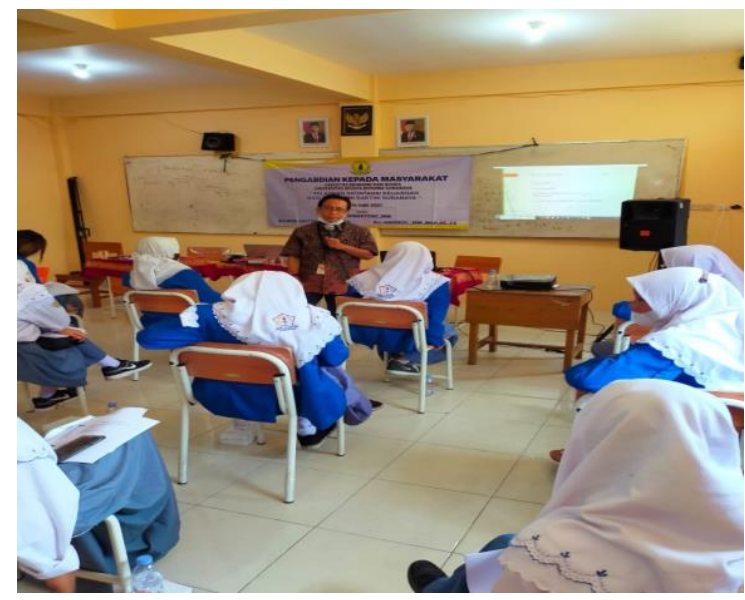

Gambar 1. Pendalaman Materi Oleh Pengabdi konseptual persamaan dasar akuntansi sebagai implementasi laporan posisi keuangan serta mampu Menyusun laporan posisi keuangan yang sesuai dengan standar akuntansi yang berlaku umum

5. Peserta mampu memahami konseptual laporan laba rugi dan mampu Menyusun laporan laba rugi perusahaan yang sesuai dengan standar akuntansi yang berlaku umum

6. Peserta mampu memahami secara konseptual laporan arus kas dan laporan perubahan ekuitas dan mampu Menyusun laporan arus kas dan laporan perubahan ekuitas yang sesuai dengan standar akuntansi yang berlaku umum

Gambar berikut adalah hasil dari kegiatan pengabdian masyarakat pada SMK Kartini Surabaya

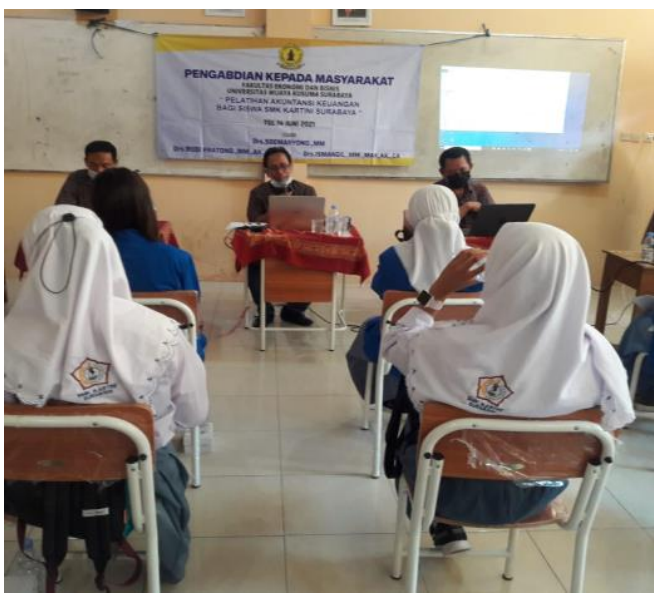

Gambar 2. Kegiatan Praktek Penyusuna Laporan Keuangan

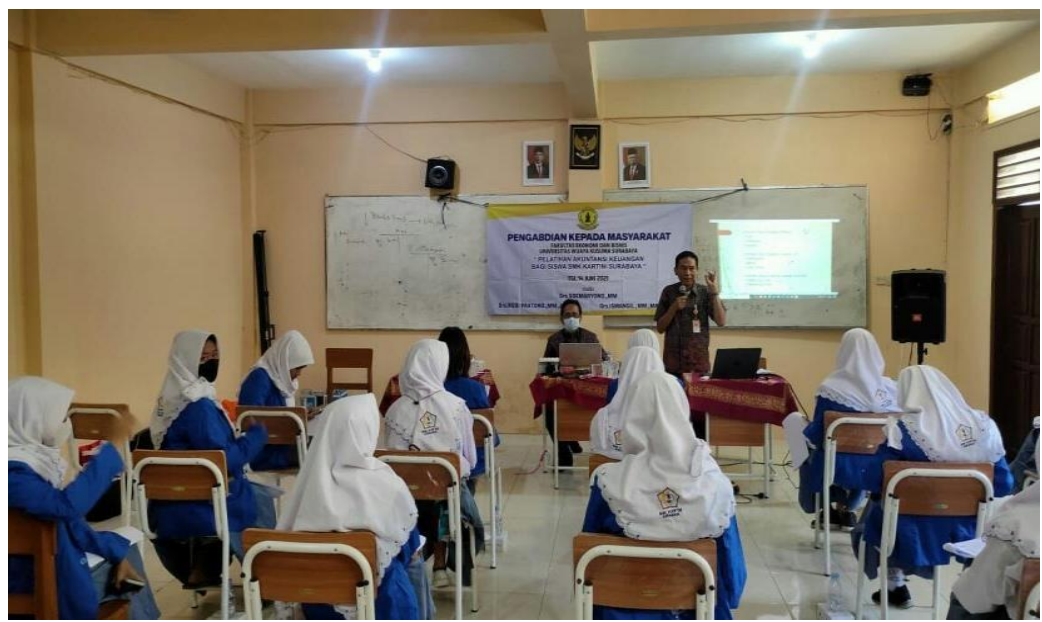

Gambar 3. Forum Diskusi 


\section{PENUTUP}

Kesimpulan dalam kegiatan pelaksanaan pengabdian kepada masyarakat

1. Para pendidik baik kepala sekolah maupun para guru di SMK kartini Surabaya sangat Terbuka sekali kegiatan ini karena menambah wawasan dan pengetahuan bidang akuntansi bagi para siswanya, apalagi siswa yang diikutkan kegiatan adalah siswa dari jurusan atau program studi akuntansi

2. Materi konsep-konsep akuntansi yang diberikan dalam materi pelatihan kegiatan ini sangat bermanfaat bagi siswa , sehingga pemahaman siswa tidak hanya melaui hafalan saja.

3. Para peserta atau siswa yang mengikuti kegiatan mengerti dan memahami laporan keuangan yang disusun berdasarkan standar akuntansi keuangan (SAK) yang berterima umum.

\section{DAFTAR PUSTAKA}

Bintari, W. C., et al.. (2019). Pelatihan Penyusunan Laporan Keuangan Secara Sederhana Pada Mahasiswa Fakultas Ekonomi Universitas Muhammadiyah Sorong. Abdimas: Papua Journal of Community Service, 1(2), 6-13. Edisi 2, Penerbit : Salemba Empat
Ikatan Akuntan Indonesia, Standar Akuntansi Keuangan, Tahun 2021, Penerbit : Salemba Empat

Jerry J.Weygandt., Paul D.Kimmel., Donald E.Kieso, Pengantar Akuntansi 1 Berbasis IFRS (e2),

Nurhayati, N., et al. (2020). Pemberdayaan Pengelolaan Keuangan Dalam Meningkatkan Kemampuan Manajerial Bagi Pelaku Usaha Di Desa Warnasari Kecamatan Pangalengan Kabupaten Bandung. Kaibon Abhinaya: Jurnal Pengabdian Masyarakat, 2(2), 66-70.

Putra, IGS., Rachmat, RAH., (2019). Characteristics of Management Accounting Systems, Implementation of Accounting Information Systems and Managerial Performance. International Journal of Advanced Science and Technology. 28(6) . 01-07

Suwardjono, Teori Akuntansi, Edisi Ketiga, Tahun 2005, Penerbit : BPFE Yogjakarta

Theodorus M.Tuanakotta, Teori Akuntansi, 2000, Penerbit : LPFE-UI

Yadiati Winwin, Teori Akuntansi Suatu Pengantar, Tahun 2015, Penerbit : Prenadamedia Grup

Zaki Baridwan, Intermediat Accounting, Edisi 8, Tahun 2016, Penerbit : BPFE Yogjakarta 